\title{
Influence of Ante-Slaughtering Factors on Broiler Meat Acidity
}

\author{
Marius Mihai CIOBANU ${ }^{1) *}$, Roxana LAZĂR ${ }^{1)}$, Alina Narcisa POSTOLACHE ${ }^{2)}$, Paul Corneliu BOIȘTEANU ${ }^{1)}$ \\ ${ }^{1}$ ) Department of Fundamental Sciences in Animal Husbandry, "Ion Ionescu de la Brad" University of \\ Applied Life Sciences and Environment, 8 MihailSadoveanu Alley, 700489, Iași, Romania \\ 2) Cattle Breeding Research Station from Dancu, Iași - Ungheni road 9, 707252, Iaşi, Romania \\ *Corresponding author, email: mar.ciobanu@yahoo.com
}

Bulletin UASVM Animal Science and Biotechnologies 72(2) / 2015

Print ISSN 1843-5262; Electronic ISSN 1843-536X

DOI:10.15835/buasvmcn-asb:11085

\begin{abstract}
Our study evaluated the acidity of broiler meat in accordance with some ante-slaughtering factors such as: duration of transport from farm to slaughterhouse, broilers' density in transport shelves and ante-slaughtering rest time. To carry out the current study, three experimental batches were prepared; $\mathrm{pH}$ determination was made at $0.25,12$ and $24 \mathrm{~h}$ after slaughter.After slaughtering, dynamics of pH placed the carcasses of batches L1 and L2 in a safety interval, while carcasses from L3 batch presented signs of PSE. A possible explication of this causeeffect relationship could be the insufficient ante-slaughtering rest period (30 min.) and moderate density during transport (32 chicken/shelf), even if the distance was the shortest one (4 km).
\end{abstract}

Keywords: acidity, ante-slaughtering, glycogen

\section{INTRODUCTION}

Gathering, loading and operations implied in transport are stressful operations for birds, in which muscular activity is more intense. All of these determine an ante-slaughtering acceleration of ATP and glycogen consumption. The birds to be slaughtered have small quantities of glycogen and lactic acid, so the acidification of musculature will be lower, determining the incomplete decrease of pH (Pèrez-Alvarez and Fernández-Lõpez, 2006; Pèrez-Alvarez, 2006). Therefore, a rapid decrease of $\mathrm{pH}$ leads to defects in the meat(PSE and DFD), the final value of those parameters influencing preservation and technological features of meat (Prändl, 1994; Sayas-Barberá et al., 2010).

\section{AIMS AND OBJECTIVES}

The aim of the current research was to evaluate the acidity of broiler meat under the effect of some ante-slaughtering factors (transport duration, density in shelves and the rest period in slaughter house), correlated with a post-slaughtering dynamics.

\section{MATERIALS AND METHODS}

To carry out the study, three experimental batches were formed (100/experimental batch); the biological material was "ROSS 308" broilers, aged 42 days, gathered from three rearing farms: SIMILA farm, situated at a distance of $152 \mathrm{~km}$, transport duration of 165 minutes with a chicken density in shelves of 28 and a rest time of 90 minutes after arrival in the slaughterhouse (L1); DOINA farm, situated at a distance of $107 \mathrm{~km}$ from the slaughterhouse, transport duration of 105 minutes with a chicken density in shelves of 30 and a rest time of 60 minutes (L2) andHENCI farm, placed $4 \mathrm{~km}$ from the slaughterhouse, transport duration of 15 minutes, with a chicken density in shelves of 32 and a rest time of 30 minutes (L3). 
Tab.1 Chickens' meat acidity for experimental batches L1, L2, L3

\begin{tabular}{|c|c|c|c|c|c|c|}
\hline \multirow{3}{*}{$\begin{array}{l}\text { Refrigeration } \\
\text { time (h) }\end{array}$} & \multirow{2}{*}{$\begin{array}{l}\text { Exp. } \\
\text { batch }\end{array}$} & \multicolumn{5}{|c|}{ HYBRID “ROSS-308” ( $\mathrm{n}=100$ /experimental batch) } \\
\hline & & \multirow{2}{*}{$\frac{\bar{X} \pm s_{\bar{x}}}{6.64 \pm 0.032}$} & \multirow{2}{*}{$\frac{\mathrm{V} \%}{1.525}$} & \multirow{2}{*}{$\frac{\text { Min. - Max. }}{6.46-6.73}$} & \multicolumn{2}{|c|}{$\begin{array}{l}\text { Interpretation of differences } \\
\text { T-Test (2-tailed) } \\
\end{array}$} \\
\hline & L1 & & & & L1-L2 & $\mathrm{t}=1.450 ; \mathrm{p}=0.181^{\mathrm{ns} .}$ \\
\hline \multirow[t]{2}{*}{0.25} & L2 & $6.57 \pm 0.041$ & 1.965 & $6.39-6.79$ & L1-L3 & $\mathrm{t}=6.946 ; \mathrm{p}=0.000^{* * *}$ \\
\hline & L3 & $6.25 \pm 0.048$ & 2.443 & $6.05-6.52$ & L2-L3 & $\mathrm{t}=4.786 ; \mathrm{p}=0.001^{* * *}$ \\
\hline \multirow{3}{*}{12} & L1 & $6.54 \pm 0.032$ & 1.548 & $6.36-6.63$ & L1-L2 & $\mathrm{t}=1.450 ; \mathrm{p}=0.181^{\mathrm{ns} .}$ \\
\hline & L2 & $6.47 \pm 0.041$ & 1.995 & $6.29-6.69$ & L1-L3 & $\mathrm{t}=6.946 ; \mathrm{p}=0.000^{* * *}$ \\
\hline & L3 & $6.15 \pm 0.048$ & 2.482 & $5.95-6.42$ & L2-L3 & $\mathrm{t}=4.786 ; \mathrm{p}=0.001^{* * *}$ \\
\hline \multirow{3}{*}{24} & L1 & $6.27 \pm 0.087$ & 4.367 & $5.86-6.66$ & L1-L2 & $\mathrm{t}=0.746 ; \mathrm{p}=0.474^{\mathrm{ns} .}$ \\
\hline & L2 & $6.16 \pm 0.136$ & 8.030 & $5.62-6.58$ & L1-L3 & $\mathrm{t}=7.346 ; \mathrm{p}=0.000^{* * *}$ \\
\hline & L3 & $5.61 \pm 0.028$ & 1.606 & $5.46-5.74$ & L2-L3 & $\mathrm{t}=3.884 ; \mathrm{p}=0.004^{* *}$ \\
\hline
\end{tabular}

significant differences $(\mathrm{p}<0.01) ;{ }^{* * *}$ very significant differences $(\mathrm{p}<0.001)$.

Determination of the $\mathrm{pH}$ value for all those three batches was made at $0.25,12$ and $24 \mathrm{~h}$ after slaughtering in accordance with the analysis principle described by standard SR ISO 2917:2007.

\section{RESULTS AND DISCUSSION}

In the phase ofpre-rigor mortis, $0.25 \mathrm{~h}$ after slaughtering, the meat gathered from the chickens was characterised by $\mathrm{pH}$ values, which had the means of $6.64 \pm 0.032\left(\mathrm{~L}_{1}\right), 6.57 \pm 0.041$ $\left(\mathrm{L}_{2}\right)$ and $6.25 \pm 0.048\left(\mathrm{~L}_{3}\right)$, dynamics enlightened a parallelism between batches in the first 12 hours of refrigeration till mean values of $6.54 \pm 0.032\left(\mathrm{~L}_{1}\right)$, $6.47 \pm 0.041\left(\mathrm{~L}_{2}\right)$ and $6.15 \pm 0.048\left(\mathrm{~L}_{3}\right)$.

At the end of the refrigeration period, $\mathrm{pH}$ values highlight an accentuated decrease inchicken from batch $\mathrm{L}_{3}$ comparedto the one observed at chicken from batches $\mathrm{L}_{1}$ and $\mathrm{L}_{2}$, a situation reflected by the calculated means: $6.27 \pm 0.087\left(\mathrm{~L}_{1}\right), 6.16 \pm 0.156$ $\left(\mathrm{L}_{2}\right)$ and $5.61 \pm 0.028\left(\mathrm{~L}_{3}\right)$ (Table 1).

Primary statistical estimators calculated for the obtained data, which characterized the dispersion degree of slaughtered broilers' meat acidity values, were reduced, the variation coefficient displayed inferior values to the level of $10 \%$, a fact which showed a very good homogeneity between individuals from each experimental batch (Table 1).

\section{CONCLUSION}

$\mathrm{pH}$ dynamics presented a descendant trend in the first $24 \mathrm{~h}$ post-mortem, the $\mathrm{pH}$ recorded values for carcasses of batch L3having an accentuated decrease in comparison with the one observed at batches L1 and L2. Carcasses of batches L1 and L2 were in the safety interval, while carcasses of batch L3 presented PSE signs. A possible explanation for the cause-effect relationship could be the insufficient ante-slaughtering rest time (30 min.) and moderate density during transport (32 chicken/shelf) even if the distance was the shortest (4 km).

\section{REFERENCES}

1. Pèrez-Alvarez JA (2006). Color de la carne y productoscárnicos, In: Hui Y.H., Guerrero I., Rosmini M.R. Edition, Ciencia y Tecnología de Carnes, 161-198.

2. Pèrez-Alvarez JA Fernández-Lõpez J (2006). Chemistry and biochemistry of colour in muscle foods, In: Hui Y.H., Nip W.K., Leo Nollet M.L., Paliyath G., Simpson B.K. Edition, Food Biochemistry and Food Processing, Ames, Blackwell Publishing, 337-350.

3. Prändl A (1994). Il sacrificio de losanimales, con excepciõn de las aves, In: Prändl O., Fisher A., Schmidhofer T., Sinell H.J., Edition, Tecnologìa e Higiene de la Carne.

4. Sayas-Barberá E, Fernández-Lõpez J, Sendra-Nadal E (2010). Biochemical changes during onset and resolution of rigor mortis under ambient temperature, Handbook of Poultry Science and Technology, 2019 - 241. 